\title{
КЛЮЧОВІ НАПРЯМКИ УДОСКОНАЛЕННЯ ПОКАЗНИКІВ БЮДЖЕТНИХ ПРОГРАМ: ОБЛІКОВИЙ АСПЕКТ
}

\section{KEY DIRECTIONS FOR IMPROVING THE INDICATORS OF BUDGET PROGRAMS: ACCOUNTING ASPECT}

\author{
Коритник Лілія Петрівна \\ кандидат економічних наук, докторант, головний бухгалтер, \\ Державна навчально-наукова установа «Академія фрінансового управління» \\ ORCID: https://orcid.org/0000-0002-7241-9324
}

\author{
Korytnyk Liliya \\ State Educational and Scientific Establishment \\ «The Academy of Financial Management»
}

\begin{abstract}
Задля прозорості, відкритості та посилення ефективності управління державними фрінансами важливо модернізувати систему результативних показників бюджетних програм. Доведено, що сучасний склад результативних показників бюджетних програм не забезпечує транспарентність бюджетного процесу в частині інтерпретації інформації про ефективність використання бюджетних коштів. Це дало змогу визначити напрямки удосконалення показників бюджетних програм через оприлюднення інфрормації про обсяг та структуру видатків та доповнення показників таким як «собівартість державних послуг», що дозволить розпорядникам бюджетних коштів, громадянам та іншим зацікавленим користувачам отримати необхідну релевантну обліково-аналітичну інформацію про державні видатки залежно від їх економічного змісту та цільового призначення. Такий підхід забезпечить розкриття інорормації про обсяги, напрями та економічну характеристику державних видатків, що відповідатиме задекларованим векторам державної політики щодо транспарентності бюджетного процесу.

Ключові слова: бюджетна програма, видатки, державні послуги, собівартість, фрінансування.
\end{abstract}

Для прозрачности, открытости и усиления эффрективности управления государственными ффинансами важно модернизировать систему результативных показателей бюджетных программ. Доказано, что современный состав результативных показателей бюджетных программ не обеспечивает транспарентность бюджетного процесса в части интерпретации информации об эфффективности использования бюджетных средств. Это позволило определить направления совершенствования показателей бюджетных программ путем обнародования инорормации об объеме и структуре расходов и дополнения показателей таким как «себестоимость государственных услуг», что позволит распорядителям бюджетных средств, гражданам и другим заинтересованным пользователям получить необходимую релевантную учетно-аналитическую инфрормацию о государственных расходах в зависимости от их экономического содержания и целевого назначения. Такой подход обеспечит раскрытие информации об объемах, направлениях и экономической характеристике государственных расходов, что соответствует задекларированным векторам государственной политики по транспарентности бюджетного процесса.

Ключевые слова: бюджетная программа, расходы, государственные услуги, себестоимость, фринансирование.

The degree of achievement of public policy objectives in the relevant area is revealed through the performance indicators of budget programs, which are used to assess the effectiveness of public finance management in the areas of use of budget funds, including the effectiveness of public services. The current composition of the performance indicators of budget programs does not ensure the transparency of the budget process in terms of disclosure of information on the effectiveness of the use of budget funds. In order to ensure transparency and openness of budget managers and increase the efficiency of public finance management, it is important to modernize the system of performance indicators of budget programs. The purpose of the article is to determine the main directions of reforming the indicators of budget programs for transparency in the use of budget funds by public sector entities and increase the efficiency of public finance management. The method of system analysis, methods of causeand-effect analysis, tabular method were used. It is proved that the current composition of performance indicators of budget programs does not ensure transparency of the budget process in terms of interpretation of information on the effectiveness of the use of budget funds. This made it possible to identify areas for improvement of budget 
programs through the disclosure of information on the amount and structure of expenditures and additions such as "cost price of public services", which will allow key budget managers, citizens and other interested users to obtain the necessary relevant accounting and analytical information on public expenditures. depending on their economic content and purpose. This approach will ensure the disclosure of information on the volume, direction and economic characteristics of public expenditures and will establish their comparability with the budget program and the degree of achievement of public policy goals in the relevant field, which will correspond to the ideology of program-target method in the budget process.

Keywords: budget program, expenditures, public services, cost, financing.

Постановка проблеми. Побудова ефективної національної економіки передбачає проведення реформ системи управління державними орінансами, яка є основою для реалізації державної політики і досягнення стратегічних цілей розвитку шляхом забезпечення економічно обґрунтованого бюджетного планування, ефрективного розподілу бюджетних коштів та якісного надання державних послуг. Система управління державними фрінансами не повною мірою відповідає вимогам сьогодення. Проявом її недостатньої ефективності $\epsilon$ відсутність порядку фрормування собівартості державних послуг, недосконалий механізм розподілу бюджетного фрінансування, низький рівень доступності і транспарентності в управлінні бюджетними коштами, відсутність взаємозв'язку між бюджетними програмами та результатами їх виконання.

Ступінь досягнення цілей державної політики у відповідній сфрері розкривається через результативні показники бюджетних програм, які використовуються для оцінки ефективності управління державними фрінансами за напрямами використання бюджетних коштів, у тому числі ефективності надання державних послуг.

Сучасний склад результативних показників бюджетних програм не забезпечує транспарентність бюджетного процесу в частині розкриття інфрормації про ефрективність використання бюджетних коштів. Ключовим показником, який характеризує ефективність використання державних ресурсів та забезпечує оцінку діяльності будь-якого суб'єкта $є$ агреговані прямі й загальновиробничі витрати, які фрормують економічний показник «собівартість державних послуг».

Розкриття інорормації про показник собівартості державних послуг та його структуру не передбачено в складі результативних показників виконання бюджетних програм. Це свідчить про відсутність зв'язку показника собівартості з фрінансовим результатом діяльності суб'єктів державного сектору та ефективністю використання державних фрінансових ресурсів на цілі і завдання бюджетної програми.
В цих умовах актуалізується питання визначення напрямів вдосконалення показників бюджетних програм з метою підвищення есрективності та транспарентності у використанні бюджетних коштів.

Аналіз останніх досліджень і публікацій. 3 часу проголошення модернізації системи управління державними фрінансами та ресрормування системи бухгалтерського обліку в державному секторі вітчизняними науковцями активно проводять дослідження напрямів удосконалення управління використанням бюджетних коштів та їх облікове забезпечення. Проблеми бухгалтерського обліку, звітування та фрінансового управління суб'єктів державного сектору досліджують вчені: Л.В. Гізатуліна, О.О. Дорошенко, Т.І. Єфрименко, Л.Г. Ловінська, С.В. Свірко, Н.І. Сушко та інші [1-6]. Не применшуючи цінності, важливості і значення результатів досліджень вказаних науковців, варто зауважити, що обліковий аспект напрямів удосконалення показників бюджетних програм залишаються поза увагою предметного поля дослідження вчених.

Формулювання цілей статті (постановка завдання). Метою статті $€$ визначення основних напрямків ресрормування показників бюджетних програм задля транспарентності у використанні бюджетних коштів суб'єктами державного сектору та підвищення ефрективності управління державними фрінансами.

Виклад основного матеріалу дослідження. Програмою діяльності Кабінету Міністрів України від 04.10.2019 р. №188-ІХ [7] передбачено продовження та прискорення подальшого розкриття інфрормації про публічні орінанси, забезпечення публічності та прозорості, регулярне оновлення і розповсюдження звітів та актуальних важливих змін і подій в економіці країни.

Стаття 28 Бюджетного кодексу України «Доступність інфрормації про бюджет» визначає коло суб'єктів та склад інорормації, яка підлягає оприлюднення ними. Так, наприклад, головні розпорядники бюджетних коштів оприлюднюють шляхом розміщення на своїх офріційних сайтах: паспорти бюджетних програм 
на поточний бюджетний період (включаючи зміни до паспортів бюджетних програм); звіти про виконання паспортів бюджетних програм за звітний бюджетний період; звіти про хід реалізації державних інвестиційних проектів; результати оцінки едективності бюджетних програм за звітний бюджетний період [8].

Ряд показників зазначених документів, які підлягають оприлюдненню, ґрунтується на даних управлінського обліку суб'єктів державного сектора про що безпосередньо зазначається в колонці «Джерело інфрормації» таких документів. Наприклад, в паспорті бюджетної програми та звіті про його виконання за кодом програмної класифрікації видатків 2201160 «Підготовка кадрів вищими навчальними закладами III i IV рівнів акредитації та забезпечення діяльності їх баз практики» (далі - КПКВ 2201160) на основі даних управлінського обліку фрормуються наступні показники затрат, продукту, еорективності та якості (таблиця 1).

Однак, склад показників зазначеної бюджетної програми не відповідає своїй економічній сутності та не відображає ефрективність використання бюджетних коштів і якість управління державними орінансами, так:

- показник «затрати» не містить складових у вартісному вимірнику, а відображає середньорічну чисельність персоналу та середньорічну кількість фрахівців;

- показник «едеективність» відображає середні витрати на підготовку фахівців, що не дозволяє об'єктивно оцінити обсяги та структуру державних видатків на підготовку фрахівців;

- показник «якості» відображає питому вагу фрахівців, які отримали документ про освіту у загальному обсязі випуску, що по суті відповідає показнику «продукту» в частині висвітлення даних про кількість випускників і жодним чином не свідчить про якість виконання бюджетної програми.

Вочевидь, такий склад результативних показників бюджетних програм не забезпечує транспарентність бюджетного процесу в частині інтерпретації інсрормації про ефрективність використання бюджетних коштів.

Основним показником, який характеризує есрективність використання державних ресурсів та забезпечує оцінку діяльності будь-якого суб'єкта є систематизовані прямі й загальновиробничі витрати, які фрормують економічний показник «собівартість державних послуг». 3 огляду на зазначене, необхідно модернізувати систему результативних показників бюджетних програм через оприлюднення інсрормації про обсяг та структуру видатків та введення показника «собівартість» державних послуг, що дозволить головним розпорядникам бюджетних коштів, громадянам та іншим зацікавленим користувачам отримати необхідну релевантну обліково-аналітичну інформацію про державні видатки залежно від їх економічного змісту та цільового призначення, зокрема щодо видатків на заробітну плату, придбання матеріальних активів, послуги сторонніх організації, спожиті комунальні послуги, відрядження та інше.

Щодо формування інфрормації про собівартість державних послуг за КПКВ 2201160, вважаємо, що акумулюючи дані системи управлінського обліку, в бюджетній програмі доцільно розкривати інфрормацію про витрати і собівартість в розрізі галузей знань, за якими здійснюється підготовка здобувачів вищої освіти для відображення розгорнутих даних про обсяги та напрями державних витрат на підготовку фрахівців певного профрілю. Це забезпечуватиме реалізацію ключових принципів відкритості використання бюджетних коштів та доступу до публічної інфрормації, сприятиме прозорості бюджетного процесу та фрормуванню шляхів оптимізації використання бюджетних коштів, пов'язаних з наданням та забезпеченням надання відповідних державних послуг та реалізацією мети і завдань бюджетної програми.

Враховуючи положення наказу Міністерства фрінансів України (далі - МФУ) від 29.12.2002 № 1098 «Про паспорти бюджетних програм» [9], паспорт бюджетної програми фрормується з використанням інфрормації, наведеної у бюджетному запиті головного розпорядника. 3 огляду на зазначене, найдоцільніше реалізувати пропозицію по відображенню даних щодо обсягів бюджетних видатків з урахуванням та на основі інфрормації, яку головні розпорядники бюджетних коштів продукують при підготовці бюджетного запиту. Так, відповідно до п. 2.4. наказу МФУ від 06.06.2012 № 687 «Про затвердження Інструкції 3 підготовки бюджетних запитів» [10] розрахунок обсягів видатків на плановий та наступні за плановим два бюджетні періоди здійснюється за кожною бюджетною програмою як за загальним, так і за спеціальним фондами в розрізі кодів економічної класифікації видатків бюджету (далі - KЕКВ) та відображається в таблицях 5.1 та 5.3 «Видатки за кодами економічної класифрікації видатків бюджету у 20_-20_ роках» індивідуального бюджетного запиту (Форма-2 - додаток 2 до Інструкції з підготовки бюджетних запитів). 
Перелік результативних показників паспорта бюджетної програми

та звіту про його виконання за КПКВ 2201160, інформація про які продукується системою управлінського обліку

\begin{tabular}{|c|c|}
\hline $\begin{array}{c}\text { Показник } \\
\text { бюджетної } \\
\text { програми }\end{array}$ & $\begin{array}{c}\text { Складові показника бюджетної програми, } \\
\text { джерелом яких є дані управлінського обліку }\end{array}$ \\
\hline Затрат & $\begin{array}{l}\text { Всього середньорічне число штатних одиниць (в тому числі): } \\
\text { Адмінперсоналу за умовами оплати праці віднесеного до науково- } \\
\text { педагогічного персоналу } \\
\text { Науково-педагогічного персоналу } \\
\text { Педагогічного персоналу } \\
\text { Спеціалістів } \\
\text { Робітників } \\
\text { Середньорічна кількість аспірантів, які навчаються без відриву } \\
\text { від виробництва } \\
\text { Середньорічна кількість аспірантів, які навчаються з відривом } \\
\text { від виробництва } \\
\text { Середньорічна кількість докторантів } \\
\text { Середньорічна кількість студентів денної форори навчання } \\
\text { Середньорічна кількість студентів заочної форми навчання } \\
\text { Середньорічна кількість студентів вечірньої форми навчання } \\
\text { Середньорічна кількість дітей-сиріт на повному державному забезпеченні } \\
\text { Середньорічна кількість дітей-сиріт під опікою }\end{array}$ \\
\hline Продукту & $\begin{array}{l}\text { Випуск аспірантів, які навчаються з відривом від виробництва та успішно } \\
\text { завершили навчання } \\
\text { Випуск аспірантів, які навчаються з відривом від виробництва } \\
\text { Випуск докторантів } \\
\text { Випуск докторантів, які успішно завершили навчання і захистили дисертації } \\
\text { Кількість студентів, прийнятих на перший курс за денною формою навчання } \\
\text { (бакалавр) } \\
\text { Кількість осіб з числа дітей-сиріт та дітей, позбавлених батьківського } \\
\text { піклування, яким виплачено щорічну допомогу для придбання навчальної } \\
\text { літератури } \\
\text { Кількість одержувачів адресної допомоги із числа випускників, які навчалися } \\
\text { за педагогічними та медичними спеціальностями } \\
\text { Кількість випускників з числа дітей-сиріт та дітей позбавлених батьківського } \\
\text { піклування, яким виплачено одноразову грошову допомогу при } \\
\text { працевлаштуванні } \\
\text { Кількість випускників денної фрорми навчання (спеціалісти і магістри) }\end{array}$ \\
\hline Еорективності & $\begin{array}{l}\text { Середні витрати на навчання одного аспіранта, який навчається без відриву } \\
\text { від виробництва } \\
\text { Середні витрати на навчання одного аспіранта, який навчається з відривом } \\
\text { від виробництва } \\
\text { Середні витрати на навчання одного докторанта } \\
\text { Середні витрати на навчання одного студента (приведений контингент) }\end{array}$ \\
\hline Якості & $\begin{array}{l}\text { Питома вага студентів, які отримали відповідний документ про освіту } \\
\text { у загальному обсязі випуску } \\
\text { Питома вага осіб, прийнятих на денну форму навчання за державним } \\
\text { замовленням у загальному обсязі прийому } \\
\text { Питома вага працевлаштованих випускників денної фрорми навчання } \\
\text { у загальному обсязі випускників денної форми навчання } \\
\text { Питома вага аспірантів та докторантів, які успішно завершили навчання } \\
\text { та захистили дисертації у загальному обсязі випуску }\end{array}$ \\
\hline
\end{tabular}

Джерело: сформовано на основі паспорта бюджетної програми та звіту про його виконання за КПКВ 2201160 
Відображення та деталізація видатків в паспортах бюджетних програм в розрізі КЕКВ дозволить громадянам та зацікавленим користувачам отримати необхідну кількість релевантної обліково-аналітичної інсрормації про видатки залежно від їх економічного змісту та цільового призначення, зокрема щодо видатків на заробітну плату, придбання матеріальних активів, послуги сторонніх організації, спожиті комунальні послуги, відрядження та інше (таблиця 2).

При цьому, розмір витрат на підготовку фрахівців важливо розкривати в розрізі учасників освітнього процесу та цільового характеру бюджетних коштів, що забезпечить відображення інорормації про склад витрат на підготовку студента, слухача, аспіранта, докторанта та про домінування витрат безпосередньо на підготовку фрахівців (прямі витрати) чи утримання установи (загальновиробничі витрати).

Вочевидь, важливо зробити методологічні зміни до підходу бюджетного планування та програмно-цільового методу в контексті побудови правил і принципів бюджетного процесу, які ґрунтуватимуться на застосуванні показника собівартості державних послуг, як ключового індикатора універсального механізму встановлення економічно обґрунтованого обсягу бюджетного фрінансування та визначення вартості державних послуг в межах головних розпорядників бюджетних коштів. При цьому, необхідно забезпечити дотримання норм НП(С)БОДС 135 «Витрати» [11] В частині розкриття інфрормації про структуру собівартості (прямі і загальновиробничі витрати) (таблиця 3).

Таблиця 2

Пропозиції з удосконалення розділу 9 «Напрями використання бюджетних коштів» паспорта бюджетної програми за КПКВ 2201160

\begin{tabular}{|c|c|c|c|c|}
\hline $\begin{array}{l}\text { № } \\
\text { 3ா }\end{array}$ & \multicolumn{2}{|c|}{ Напрями використання бюджетних коштів } & \multirow[t]{2}{*}{$\begin{array}{c}\text { Загальний } \\
\text { фронд }\end{array}$} & \multirow[t]{2}{*}{$\begin{array}{c}\text { Спеціальний } \\
\text { фонд }\end{array}$} \\
\hline 1 & Підготовка кадрів & & & \\
\hline \multirow[t]{17}{*}{1.1.} & \multirow{2}{*}{2000 «Поточні видатки»: } & Прямі витрати & & \\
\hline & & Загальновиробничі & & \\
\hline & \multirow{2}{*}{2111 «Заробітна плата» } & Прямі витрати & & \\
\hline & & Загальновиробничі & & \\
\hline & \multirow{2}{*}{2120 «Нарахування на оплату праці» } & Прямі витрати & & \\
\hline & & Загальновиробничі & & \\
\hline & \multirow{2}{*}{$\begin{array}{l}2210 \text { «Предмети, матеріали, } \\
\text { обладнання та інвентар» }\end{array}$} & Прямі витрати & & \\
\hline & & Загальновиробничі & & \\
\hline & \multirow{2}{*}{$\begin{array}{l}2220 \text { «Медикаменти та } \\
\text { перев'язувальні матеріали» }\end{array}$} & Прямі витрати & & \\
\hline & & Загальновиробничі & & \\
\hline & \multicolumn{2}{|l|}{2230 «Продукти харчування» } & & \\
\hline & \multirow{2}{*}{$\begin{array}{l}2240 \text { «Оплата послуг } \\
\text { (крім комунальних)» }\end{array}$} & Прямі витрати & & \\
\hline & & Загальновиробничі & & \\
\hline & \multirow{2}{*}{2250 «Видатки на відрядження» } & Прямі витрати & & \\
\hline & & Загальновиробничі & & \\
\hline & $\begin{array}{l}2270 \text { «Оплата комунальних послуг } \\
\text { та енергоносіїв» }\end{array}$ & & & \\
\hline & 2800 «lнші поточні видатки» & & & \\
\hline \multirow[t]{7}{*}{1.2.} & \multicolumn{2}{|c|}{3000 «Капітальні видатки»: } & & \\
\hline & \multicolumn{2}{|c|}{$\begin{array}{l}3110 \text { «Придбання обладнання і предметів } \\
\text { довгострокового користування» }\end{array}$} & & \\
\hline & \multicolumn{2}{|c|}{3120 «Капітальне будівництво (придбання)» } & & \\
\hline & \multicolumn{2}{|c|}{3130 «Капітальний ремонт» } & & \\
\hline & \multicolumn{2}{|c|}{3140 «Реконструкція та реставрація» } & & \\
\hline & \multicolumn{2}{|c|}{3160 «Придбання землі та нематеріальних активів» } & & \\
\hline & \multicolumn{2}{|c|}{$\begin{array}{l}3210 \text { «Капітальні трансфрерти підприємствам } \\
\text { (установам, організаціям)» }\end{array}$} & & \\
\hline
\end{tabular}

* - курсивом позначено пропозиції автора 
Пропозиції по доповненню результативних показників бюджетної програми за КПКВ 2201160

\begin{tabular}{|c|c|c|c|c|}
\hline \multirow[b]{2}{*}{ Показники } & \multirow{2}{*}{$\begin{array}{l}\text { Одиниця } \\
\text { виміру }\end{array}$} & \multirow{2}{*}{$\begin{array}{l}\text { Джерело } \\
\text { інфрормації }\end{array}$} & \multicolumn{2}{|c|}{20 рік } \\
\hline & & & $\begin{array}{c}\text { загальний } \\
\text { фонод }\end{array}$ & $\begin{array}{c}\text { спеціальний } \\
\text { фронд }\end{array}$ \\
\hline \multicolumn{5}{|c|}{ Собівартість підготовки кадрів } \\
\hline \multicolumn{3}{|c|}{ Галузь знань $-\ll . . . . . . . . »$} & & \\
\hline Студент: & грн. & управлінський облік & & \\
\hline Прямі витрати & грн. & управлінський облік & & \\
\hline Прямі матеріальні витрати & грн. & управлінський облік & & \\
\hline Прямі витрати на оплату праці & грн. & управлінський облік & & \\
\hline Інші прямі витрати & грн. & управлінський облік & & \\
\hline Загальновиробничі витрати & грн. & управлінський облік & & \\
\hline Aспірант: & грн. & управлінський облік & & \\
\hline Прямі витрати & грн. & управлінський облік & & \\
\hline Прямі матеріальні витрати & грн. & управлінський облік & & \\
\hline Прямі витрати на оплату праці & грн. & управлінський облік & & \\
\hline Інші прямі витрати & грн. & управлінський облік & & \\
\hline Загальновиробничі витрати & грн. & управлінський облік & & \\
\hline Докторант: & грн. & управлінський облік & & \\
\hline Прямі витрати & грн. & управлінський облік & & \\
\hline Прямі матеріальні витрати & грн. & управлінський облік & & \\
\hline Прямі витрати на оплату праці & грн. & управлінський облік & & \\
\hline Інші прямі витрати & грн. & управлінський облік & & \\
\hline Загальновиробничі витрати & грн. & управлінський облік & & \\
\hline
\end{tabular}

Джерело: складено автором

Доповнення результативних показників бюджетнихпрограм таким як «собівартість» державних послуг забезпечить інтерпретацію даних про обсяги і напрями використання бюджетних коштів та сприятиме відкритості і прозорості бюджетного процесу, дозволить визначити есрективність управління державними фрінансами та встановити зв'язок між обсягом бюджетних видатків та економічним і соціальним результатом реалізації бюджетної програми.

3 огляду на зазначене, розкриття інфрормації в паспортах бюджетних програм про обсяги бюджетних видатків у розрізі КЕКВ, прямих та загальновиробничих витрат, а також показник собівартості забезпечить реалізацію ключових принципів з відкритості використання бюджетних коштів та доступу до публічної інфрормації, сприятиме прозорості бюджетного процесу та фрормуванню шляхів оптимізації використання бюджетних коштів пов'язаних 3 наданням та/ або забезпеченням надання відповідних державних послуг та реалізацією мети і завдань бюджетної програми. Такий підхід дозволить визначити есрективність управління державними фрінансами та встановити зв'язок між обсягом бюджетних видатків та економічним і соціальним результатом реалізації бюджетної програми, що відповідатиме ключовим положенням впровадження програмно-цільового методу в бюджетному процесі.

Таким чином, розкриття запропонованої інсрормації про структуру видатків в розрізі кодів економічної класифрікації видатків, понесених прямих і загальновиробничих витрат та показник собівартості в паспортах бюджетних програм:

- створить умови для методологічної інтеграції з концептуальними положеннями НП(С) БОДС 135 «Витрати»;

- забезпечить прозорість та відкритість бюджетного процесу;

- дозволить головним розпорядникам бюджетних коштів та стейкхолдерам визначити напрями використання фрінансування: на надання якісних послуг (прямі витрати) чи утримання суб'єктів державного сектору (загальновиробничі витрати);

- дозволить встановити ефрективність управління бюджетними коштами та здійснити оцінку їх відповідності цілям бюджетної програми, що передбачено умовами запровадження програмно-цільового методу в бюджетному процесі. 


\section{СПИСОК ВИКОРИСТАНИХ ДЖЕРЕЛ:}

1. Ловінська Л.Г., Гізатуліна Л.В. Світовий досвід запровадження міжнародних стандартів у бухгалтерському обліку державного сектору. Фінанси України : Наук.-теорет. та інфрорм.-практ. журн. 2012. № 6. С. $76-87$.

2. Дорошенко О.О., Галич М.І. Фінансова звітність бюджетних установ у контексті національних положень (стандартів) бухгалтерського обліку в державному секторі. Вісник Хмельницького національного університету. Економічні науки. 2012. № 2. Т. 1. С. 111-114.

3. Актуальні проблеми фрінансового управління: глобальні тенденції і національна практика : монограсрія / за ред. Т.І. Єфрименко; ДННУ «Акад. фрін. управління». Київ, 2018. С. 424-437.

4. Ловінська Л.Г. Собівартість послуг державного сектору України в контексті реформи фрінансового управління. Фінанси України. 2017. № 8. С. 58-79.

5. Ловінська Л.Г., Сушко Н.І. Тенденції ресрормування системи бухгалтерського обліку та фрінансової звітності державного сектору України. Фінанси України : Наук.-теорет. та інфрорм. практ. журн. 2012. № 7. С. 84-100.

6. Свірко С.В., Тростенюк Т.М. Бюджетна звітність як елемент управлінського обліку в контексті субординаційної системи ДЗВО. Бизнес Инфрорм. 2018. № 11(490). С. 434-440.

7. Про Програму діяльності Кабінету Міністрів України : постанова Верховної Ради України від 04.10.2019 p. № 188-IX. URL: https://zakon.rada.gov.ua/laws/card/188-20

8. Бюджетний кодекс України : від 08.07.2010 № 2456-VI. URL: http://zakon.rada.gov.ua/laws/show/2456-17

9. Про паспорти бюджетних програм : наказ МФУ від 29.12.2002 № 1098. URL: https://zakon.rada.gov.ua/ laws/show/z0047-03

10.Про затвердження Інструкції з підготовки бюджетних запитів : наказ МФу від 06.06.2012 № 687. URL: https://zakon.rada.gov.ua/laws/show/z1057-12

11. Національне положення (стандарт) бухгалтерського обліку в державному секторі 135 «Витрати» : затверджене наказом Міністерства фрінансів України від 18.05.2012 № 568. URL: http://zakon3.rada.gov.ua/laws/show/z0903-12

\section{REFERENCES:}

1. Lovinska, L. \& Gizatulina, L. (2012). Svitovyy dosvid zaprovadzhennya mizhnarodnykh standartiv u bukhhalters'komu obliku derzhavnoho sektoru [World experience in implementation of the international public sector accounting standards]. Finance of Ukraine, 6, 76-67. (in Ukrainian)

2. Doroshenko, O. (2012). Finansova zvitnist' byudzhetnykh ustanov u konteksti natsional'nykh polozhen' (standartiv) bukhhalters'koho obliku v derzhavnomu sektori [Financial reporting of budgetary institutions in the context of national regulations (standards) of accounting in the public sector]. Bulletin of Khmelnytsky National University, 2, 111-114. (in Ukrainian)

3. lefymenko, T. I. (Ed.). (2018). Aktual'ni problemy finansovoho upravlinnya: hlobal'ni tendentsiyi i natsional'na praktyka [Current problems of financial management: global trends and national practice]: monohrafiya [a monograph]. Kyiv: SESE «The Academy of Financial Management». (in Ukrainian)

4. Lovinska, L. (2017). Sobivartist' posluh derzhavnoho sektoru Ukrayiny v konteksti reformy finansovoho upravlinnya [The cost price of public sector of Ukraine services in the context of financial management reform]. Finance of Ukraine, 8, 58-79. (in Ukrainian)

5. Lovinska, L. \& Sushko, N. (2012). Tendentsiyi reformuvannya systemy bukhhalters'koho obliku ta finansovoyi zvitnosti derzhavnoho sektoru Ukrayiny [Trends of reform in accounting and financial reporting of the state sector of Ukraine]. Finance of Ukraine, 7, 84-100. (in Ukrainian)

6. Svirko, S.V. \& Trostenyuk, T.M. (2018). Byudzhetna zvitnist' yak element upravlins'koho obliku v konteksti subordynatsiynoyi systemy DZVO [Budget reporting as an element of management accounting in the context of the subordinate system of SDC]. Business Inform, 11(490), 434-440. (in Ukrainian)

7. Verkhovna Rada of Ukraine (2019). Pro Prohramu diyal'nosti Kabinetu Ministriv Ukrayiny [Action Program of the Cabinet of Ministers of Ukraine] (Order No. 188-IX, October 04). Retrieved from: https://zakon.rada.gov.ua/laws/ show/188-ix (in Ukrainian)

8. Verkhovna Rada of Ukraine (2010). Byudzhetnyy kodeks Ukrayiny [Budget Code of Ukrain] (Order No. 2456-VI, July 08). Retrieved from: http://zakon.rada.gov.ua/laws/show/2456-17 (in Ukrainian)

9. Ministry of Finance of Ukraine (2002). Pro pasporty byudzhetnykh prohram [On passports of budget programs] (Order No. 1098, December 29). Retrieved from: https://zakon.rada.gov.ua/laws/show/z0047-03 (in Ukrainian)

10. Ministry of Finance of Ukraine (2012). Pro zatverdzhennya Instruktsiyi z pidhotovky byudzhetnykh zapytiv [On approval of the Instruction on preparation of budget requests] (Order No. 687, June 06). Retrieved from: https://zakon.rada.gov.ua/laws/show/z1057-12 (in Ukrainian)

11. Ministry of Finance of Ukraine (2012). Natsional'ne polozhennya (standart) bukhhalters'koho obliku $v$ derzhavnomu sektori 135 «Vytraty» [National Regulation (Standard) of Public Sector Accounting 135 "Costs"] (Order No. 568, May 18). Retrieved from: http://zakon3.rada.gov.ua/laws/show/z0903-12 (in Ukrainian) 